\title{
Tourism industry in the new member states. Key countries and
} destinations

\author{
Maria-Irina ANA \\ The Bucharest University of Economic Studies, Bucharest, Romania \\ ana.mariairina@yahoo.com
}

\begin{abstract}
This paper provides an examination of tourism in the New Member States of the European Union in the period 2007-2015, assessing the importance of tourism for the New Member States economy and the factors that might affect this industry. Considerable research has been devoted to tourism in the developed countries from Europe, but rather less attention has been paid to tourism in the Central-Eastern Europe, the New Member States region. In this regard, the paper will start with an overview of the current state of the literature on this topic, section that precedes a presentation of European bodies and policies in the travel and tourism field. Time series will be analyzed in order to identify the key countries for tourism in the region, according to the number of international arrivals, number of international overnight stays and exports in trade. Tourism contribution and importance for the economy, key destinations in the region, EU and state-level policies in the tourism sector, as well as main challenges and opportunities in the tourism sector will be addressed, focusing on the three key countries identified, Poland, Czech Republic and Croatia, that offer tourists unique, traditional experiences, focusing on niche markets, rather than on mass-market tourism.
\end{abstract}

Keywords: European tourism, European tourism policies, New Member States, Central European destinations, types of tourism.

Please cite the article as follows: Ana, M.I. (2018), "Tourism industry in the new member states. Key countries and destinations", Management \& Marketing. Challenges for the Knowledge Society, Vol. 13, No. 1, pp. 812-830, DOI: 10.2478/mmcks-2018-0007.

\section{Introduction}

In the last thirteen years European Union has expanded its territorial and economic space towards the Central, Eastern and South-Eastern part of Europe. In 2004, 2007 and 2013 three new accession waves took place and one of the industries most impacted by this evolution of the European Union is tourism, sector considered not only a useful means for integration, stability and unity in Europe, but also a key instrument for the development of a European Identity, as also identified by Diaconescu et all. (2007).

Europe is currently the most important continent for tourism, from both outbound and inbound flows perspective. According to the latest report from the World Tourism Organization - UNWTO (2016), 51\% of the international tourist arrivals (5\% increase in 2015 compared to 2014) and 36\% of the international tourism receipts were recorded in Europe (3\% increase in 2015 compared to 2014). Furthermore, $40.3 \%$ of the international tourist arrivals and $3.4 \%$ of the international tourism receipts in Europe were reported in the EU-28. Northern Europe experienced a 7\% growth in international arrivals, while Central and Eastern Europe reported a $5 \%$ increase after a $6 \%$ decline in 2014. Hungary, Romania, Slovakia and Latvia recorded impressive growth, reporting double-digit upturn. As a consequence of terrorist attacks, tourism industry in Western Europe only grew by 3\%. France and 
Belgium being most affected, while the Netherlands, Germany and Austria reported solid growth.

In the given context, this paper aims to provide an analysis of tourism in the thirteen New Member States (NMS-13) of the European Union. Indicators such as number of arrivals, number of overnight stays and exports in travel will be taken into consideration in order to identify the main touristic destinations among the region indicated, Central, Eastern, South-Eastern Europe. Tourism industry's contribution to these countries' economy, trends and factors that attract tourists in the region, as well as the EU and state-level policies in the tourism sector will be addressed in order to have an exhaustive image and thorough understanding of the state of this sector in the key countries and regions from the NMS-13.

The main research questions this paper is based on are: How has the tourism sector in the New Member States evolved in the period 2007-2015? Which were the key countries (among the New Member States) for tourism from 2007 to 2015? What does these countries have to offer to their tourists? What tourism-related policies have been in place in the countries identified as key destinations for New Member States tourism? In order to be able to answer these questions, the paper will be structured as follows: it will start with an overview of the current state of the literature on this topic, section that precedes a presentation of European policies in the travel and tourism field. A quantitative analysis follows and this will help us identify the key countries and regions for which specific trends, factors and touristic offerings will be sketched.

\section{Literature review}

When ranking the world's top tourism destinations, UNWTO took into consideration both international tourist arrivals and international tourism receipts and it is interesting to notice that five EU-28 countries appear in both Top 10 rankings. They are Old Member States of EU - OMS-15 -, countries where tourism is a welldeveloped, major industry. Given the highly developed economies of France, UK, Spain, Italy or Germany, it is predictable that the rest of the EU-28 countries cannot compete with them, but even in these circumstances, the number of international inbound tourists in the NMS region increased on average 41\% from 2007 to 2015 compared to the $19 \%$ growth reported by the OMS-15 in the same time frame. $92 \%$ of the total number of arrivals reported in the NMS were from Europe, indicating that to a large extent this boost can be attributed to the EU accession. Yet, despite being members of the EU and having the same rights and duties as all the other members, the NMS still have a poorer reputation that affect their tourism revenues, as this sector is probably the one that wins the most from a good branding campaign and a positive image.

According to a report published by the Travel \& Tourism Council (2016), the total contribution of the tourism industry to the GDP of the NMS-13 is roughly $12 \%$, while the direct contribution is approximately 5\%. Forecasts show that the travel and tourism sector's direct contribution in the next ten years will grow by $2.8 \%$, which surpasses the growth rate for the whole Europe $-1.9 \%$.

In what regards the factors that influence tourism increase in a certain country, exchange rates fluctuations, deregulation of international air transport and the development of low-cost airlines, event particularly frequent in Europe (Sharpley and 
Telfer, 2015), increasing competition that enabled product offerings innovation, etourism expansion (Weiermair, 2003), the increasing popularity of travel as a mean to "escape" daily routine or a stressful living, as well as affluence (the populations has gained a better standard of living), and the higher mobility of working population (Hudman and Jackson, 2003, p. 25) are considered to be the most relevant.

Moreover, as to a EU Barometer on Europeans preferences towards tourism (TNS Political and Social, 2015), the main reason for returning to the same holiday destination would be the natural features of that place, and the sun or beach is the most common response and motivation for going on a holiday, followed by visiting friends or relatives. On average, more than $70 \%$ of the Europeans are going away for at least one night, their number increasing yearly. There is also a trend towards holidays outside one's own country, but still in the EU-28, only one-fifth of the Europeans taking their main holiday outside EU.

\section{EU programs and policies for tourism}

Despite the higher importance of tourism sector for EU's economy, the European institutions have just recently started to focus on this industry. Additionally, "the importance of the tourism industry in the pursuit of sustainable development [...] represents one of the major objectives of the European Union" (Bodosca, 2016, pp. 208). Therefore, starting 2001, the Commission has published a series of policy initiatives and strategies for tourism at EU level, but we cannot yet discuss about a genuine common tourism policy for all the EU members. The European policies are rather a set of actions at national level, and some scholars, for example Halkier (2010) even considers that this is one of the main weaknesses of the EU tourism industry.

Some other challenges EU has to face is to be able to cope with behavioral, technological and demographic changes, as the elderly population, people over 65, will reach $20 \%$ of the total EU population by 2020. Political, social and environmental security, safety of food and accommodation establishments or socio-cultural sustainability are also listed as some of the main challenges for tourism in the EU (Bâc, 2015). Yet, parties involved should not neglect seasonality issues, taxation and regulations in the tourism sector, bureaucracy, the difficulty of finding and retaining skilled staff (Fouloy, 2015), or the development of the new sector of collaborative economy either (Mureşan et al, 2017).

To overcome the threats that might occur in the tourism industry, the European Commission adopted in September 2011 a strategy called "Europe, the world's no. 1 tourist destination - a new political framework for tourism in Europe", initiative that concentrates on four main goals: "to stimulate competitiveness in the European tourism sector, to promote the development of sustainable, responsible, and high-quality tourism, to consolidate Europe's image as a collection of sustainable, high-quality destinations, to maximise the potential of EU financial policies for developing tourism" (European Commission, 2010, p. 7). The most important projects and initiatives that have been put in place lately are considered to be the following:

- "European Destinations of Excellence", also known as "EDEN" was launched in 2006 and focuses on sustainable tourism, as "any efforts to achieve sustainable development will fail if the impact of tourism is not taken into account" (Sardianou et all, 2015). National competitions take place annually and "destinations of excellence"

Vol. 13, No. 1, Spring, pp. 812-830, ISSN 1842-0206 | Management \& Marketing. Challenges for the Knowledge Society 
are chosen. The success of this initiative is measured in terms of number of destinations selected as European Destinations of Excellence per year and in terms of increased awareness and visibility of such lesser known/emerging destinations. Other benefits of the EDEN initiative include: an acquired pride of the local community which led to a wave of motivating energy for further improvement of their sustainable tourism offer, an increased visibility and public awareness at national and European level, an increased awareness of the importance of sustainability in tourism, greater development of sustainable tourism products and adoption of sustainable tourism management practices, a greater support from national tourism organisations at local, regional and national level and an increase in private sector investment in the destinations, an increased cooperation of local/regional tourism stakeholders, increased networking practices which allow cost sharing (e.g. common marketing projects of the EDEN Network provide international visibility for a tiny cost) and having a vast range of contacts that facilitate participation at European projects, a larger EDEN network which feeds in information coming from small destinations thereby contributing to designing policies based on inputs from the local communities rather than mediated by intermediate bodies (European Commission, 2016). Even though there are not any aggregated figures available, some destinations have experienced up to $40 \%$ increase in visitors and even up to $300 \%$ increase of overnight stays the year following the award.

- "Cycling Routes" is a program that took place in the period 2009-2011 (total budget EUR 1.9 million according to The European Cycle Route Network EuroVelo Study (2012, p. 22) and managed to develop and promote various initiatives on the Iron Curtain Trail and Cycle Tourism. It is an ambitious project that "seeks to offer opportunities to discover over 20 countries, including 14 EU Member States, on the nearly 10,500 km route from the Barents Sea to the Black Sea" (Weston, et al., 2012, p. 13), encouraging tourists to cycle between 2 cities (including across borders) during their holiday. 15 routes area already functional and by 2020 the entire network, which will total over $70 \mathrm{k} \mathrm{km}$ is expected to be completed.

- Calypso - "tourism for all", initiative implemented from 2009 to 2012 "to help disadvantaged people go on holiday while increasing tourism in the low season" (European Commission, 2017). The Calypso projects funded by the European Commission focused on four groups, namely: underprivileged young adults, aged 1830, families on low incomes, people with disabilities and people over 65 or pensioners who cannot afford to travel or feel discouraged by the challenges of organising a trip. "Tourism for Seniors" was launched in 2012 and can be seen as a continuation of Calypso, as its target is represented by seniors from Europe, aged 55+. These people count for approximately $25 \%$ of the European population and are usually individuals with increased purchasing power and leisure time; hence, a market with a significant potential.

Everything considered, it can be stated that EU bodies are increasingly aware of tourism's importance for the whole economy, but Member States should be more willing to cooperate among themselves and with the European Institutions for their common well-being. The NMS-13 have to struggle more to align to the developed countries' level of quality, to identify and exploit their competitive advantages, to increase consumers' confidence in the tourism products they sell and be able to 
compete with key players in the market. Many destinations, either from NMS-13 or any other country in the world claim that they offer excellent travel and tourism services and facilities, unique experiences, may have one-of-a-kind cultural and heritage, but the key element is to be able to differentiate themselves (Gajdošík et al, 2015). In the sections that follow, we will conduct a quantitative analysis for the countries in the region and determine the most important countries and destinations for tourism in the New Europe. These will be characterized from the specific trends, factors and touristic offerings perspective.

\section{Context and methodology}

The latest UNWTO Report acquaints that international tourist arrivals hit the peak in 2015, reaching 1184 million overnight visitors, more than 50\% of them being reported in Europe, which recorded 609 million tourist arrivals, a 27 million increase compared to 2014 . Roughly $80 \%$ of the total arrivals in Europe can be attributed to EU-28 and approximately 15\% to the NMS, which are, after the date of accession, in chronological order, the following: Czech Republic, Cyprus, Estonia, Hungary, Latvia, Lithuania, Malta, Poland, Slovakia, Slovenia, Bulgaria and Romania, Croatia. The main source of data for these countries was Eurostat, but, whenever information was missing, statistics were collected from the World Travel and Tourism Council, the World Bank Database and the World Tourism Organization.

After studying various research papers related to this topic and based on availability of data (statistical databases are not always up-to-date or complete, particularly in the developing countries), we found that, in order to be able to identify the key countries and regions for tourism in the NMS-13 region and to determine specific trends, factors and touristic offerings that make these successful, the following indicators were relevant:

- Number of Arrivals and Number of Overnight Stays - these two related indicators include visitors entering the economic area of the Member States taken into consideration. The number of arrivals include tourists and same-day non-resident visitors. Additionally, the overnight stays correspond to the number of nights spent by guests, non-resident tourists in all kinds of accommodation establishments (hotels, holiday and other short-stay accommodation, camping grounds, recreational vehicle parks and trailer parks). However, the arrivals of same-day visitors that only spend a few hours in that country (no overnight stay is recorded, the date of arrival and departure being the same) are excluded when counting the number of overnight stays.

- Exports in Travel - refer to all the goods and services tourists consume while abroad. Incoming tourists represent tourism exports.

The number of arrivals and overnight stays was considered to be relevant for countries' popularity and attractiveness. According to Dupeyras and MacCallum (2013, p. 22), "measuring visitor numbers is a direct and objective means of assessing success in tourism, with the difference between one year's figure and the next being a transparent and easily conveyed way of showing growth or decline". Exports in travel are suitable for sketching economic development, while also reflecting changing trends in destination preferences, or the influence of exchange rates fluctuations. We will analyze time series, because as a year-on-year indicator, growth in export of 
travel services shows change in performance, reflecting international appeal, value awareness (Idem, p. 24) and helping us identify trends more easily.

\section{Main statistical findings}

In this section we will analyze the tourism statistical indicators previously mentioned, with the purpose to identify the countries with the biggest number of arrivals and overnight stays, but also the biggest exporters, the NMS that receive the highest number of tourists.

\section{Tourist arrivals and overnight stays in the NMS-13 2007-2015}

According to Eurostat Statistics, the number of arrivals from all the countries in the world in the NMS-13 rose 1.4 times in 2015 compared to 2007, from 75 million to 105.5 million tourists, while the number of overnight is, as predicted, in a tight connection with the number of arrivals and follows a rather similar trend, increasing 1.3 times in 2015 compared to 2007. These evolutions are presented in Figure 1.

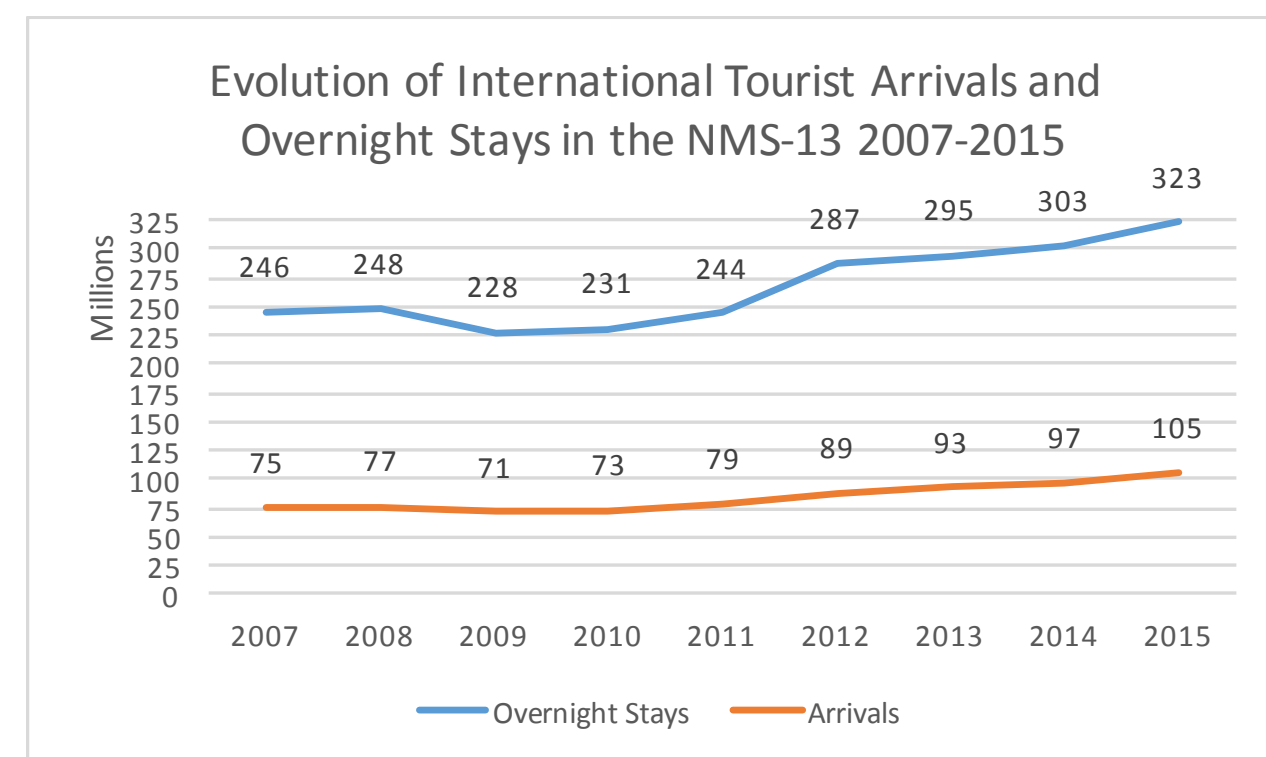

Figure 1. Evolution of international tourist arrivals and overnight stays in the NMS-13 2007-2015

Source: Author's work, based on data from Eurostat.

The global financial crisis that in September 2008 had a large impact on business tourism and tourism in general, as this sector is connected to many other sectors of the economy, both affects and is affected by a variety of other industries, such as entertainment, transport, retail, technology, health, agriculture or education.

As can be noticed from Figure 1, 2009 was the worst year for tourism in terms of tourist arrivals and overnight stays in the period 2007-2015, but this industry increased steadily afterwards. The forecasts are also promising - the "EU-28 destinations in Central and Eastern Europe are expected to grow fastest at 3.4\% a year on average through 2025" and "will overtake destinations in Northern Europe in number of international arrivals by around 2029" (World Tourism Organization, 
2016, p. 18). The international tourist arrivals in the NMS-13 for the period 20072015 are illustrated year-by-year in Figure 2.

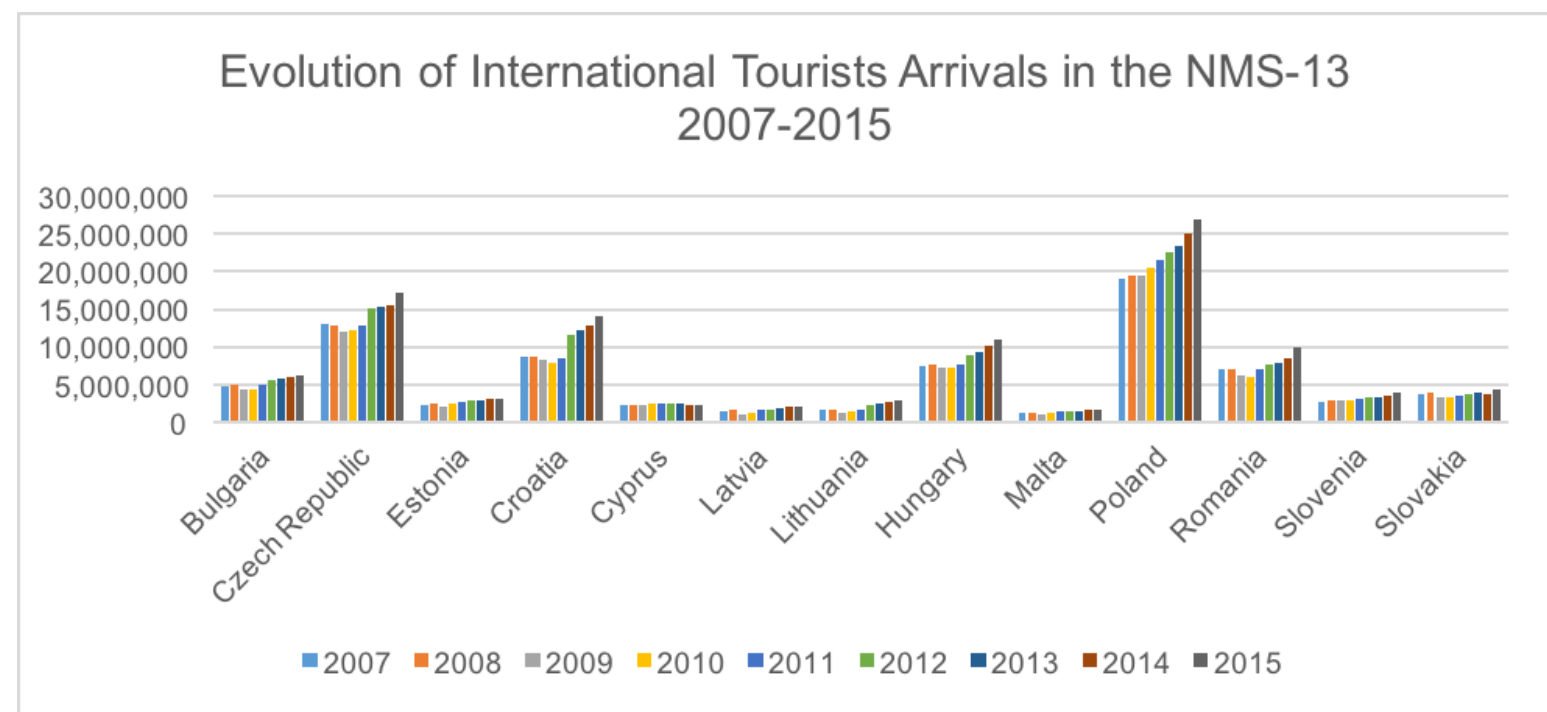

Figure 2. Evolution of international tourist arrivals in the NMS-13 2007-2015

Source: Author's work, based on data from Eurostat.

As percentage changes, the number of international arrivals increased the most in Lithuania (193\% growth), followed by Latvia (137\%), Bulgaria (88\%), Croatia (86\%) and Romania (76\%). However, in absolute terms, most of the international tourists in the NMS-13 area went to Poland (247.7 million arrivals), Czech Republic (138.5 million arrivals), and Croatia (116.6 million arrivals).

The evolution of overnight stays in the NMS-13 in the period 2007-2015 is illustrated in Figure 3. In relative terms, as expected, the number of international overnight stays increased the most in Lithuania (102\%), followed by Croatia (86\%) and Hungary (37\%). However, most of the international overnight stays in the NMS were reported by Poland (542.4 million nights), Croatia (454.7 million nights) and Czech Republic (368.5 million nights). As per Atilla (2016), these three countries are also proficient in terms of tourist service infrastructure, Croatia ranking $13^{\text {th }}$, Czech Republic $20^{\text {th }}$, and Poland $75^{\text {th }}$ out of 141 countries.

Analyzing the results provided by these two indicators, international arrivals and international overnight stays, it can be noticed that the same three countries were most popular among the NMS of the EU, namely Poland, Czech Republic and Croatia. 


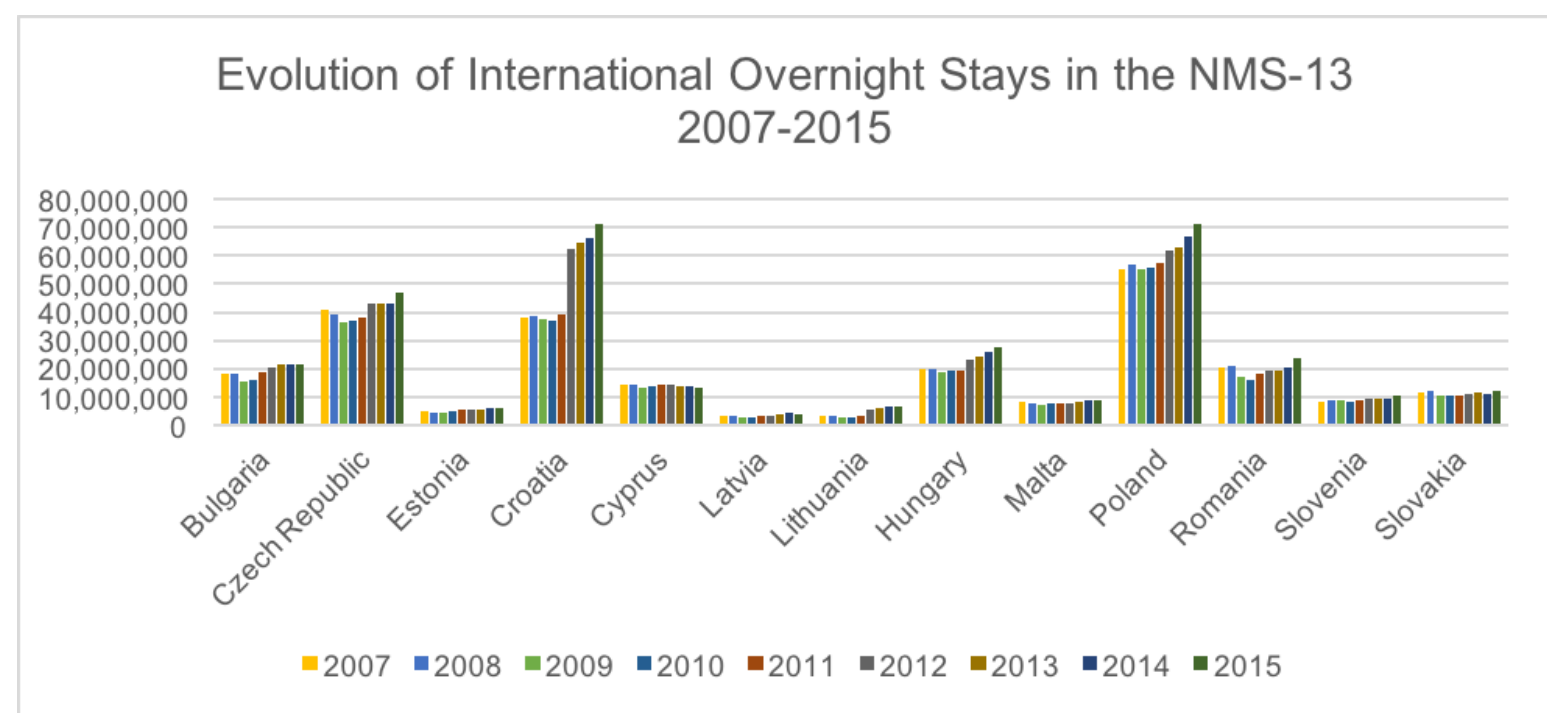

Figure 3. Evolution of international overnight stays in the NMS-13 2007-2015

Source: Author's work, based on data from Eurostat

\section{Exports in travel in the NMS-13 2007-2015}

When it comes to exports in travel, reviewing Figure 4, one can easily notice that there an ascendant trend in terms of incoming tourists, number reflected by the exports in travel reported by each country.

In 2015 exports in travel were 82\% higher than in 2007 and, in absolute terms, in amount of 42.9 thousand million in 2015 compared to 34.6 thousand million in 2007. This growth can be attributed to the increasing desire to travel manifested by people worldwide, as a consequence of a significant rise of the global middle class, consumers for whom travelling becomes part of life and it is no longer perceived as a luxury activity, and also as international travel has become more affordable. Technology development, better connectivity and intensive competition in the industry led to lower prices and better services. As members of the EU, the NMS-13 benefited from eased border crossing procedures, financial support or increased awareness, and these helped the tourism sector in the region. In order to make it easier for the reader to find the information and facts presented, we gathered all the data regarding exports in the NMS-13 in Table 1.

The countries that performed best in the period 2007-2015, reporting the highest amount of exports in travel reflected in increased international appeal and value awareness were Poland (72.4 thousand million EUR), Croatia (62.6 thousand million EUR) and Czech Republic (47.7 thousand million EUR). 


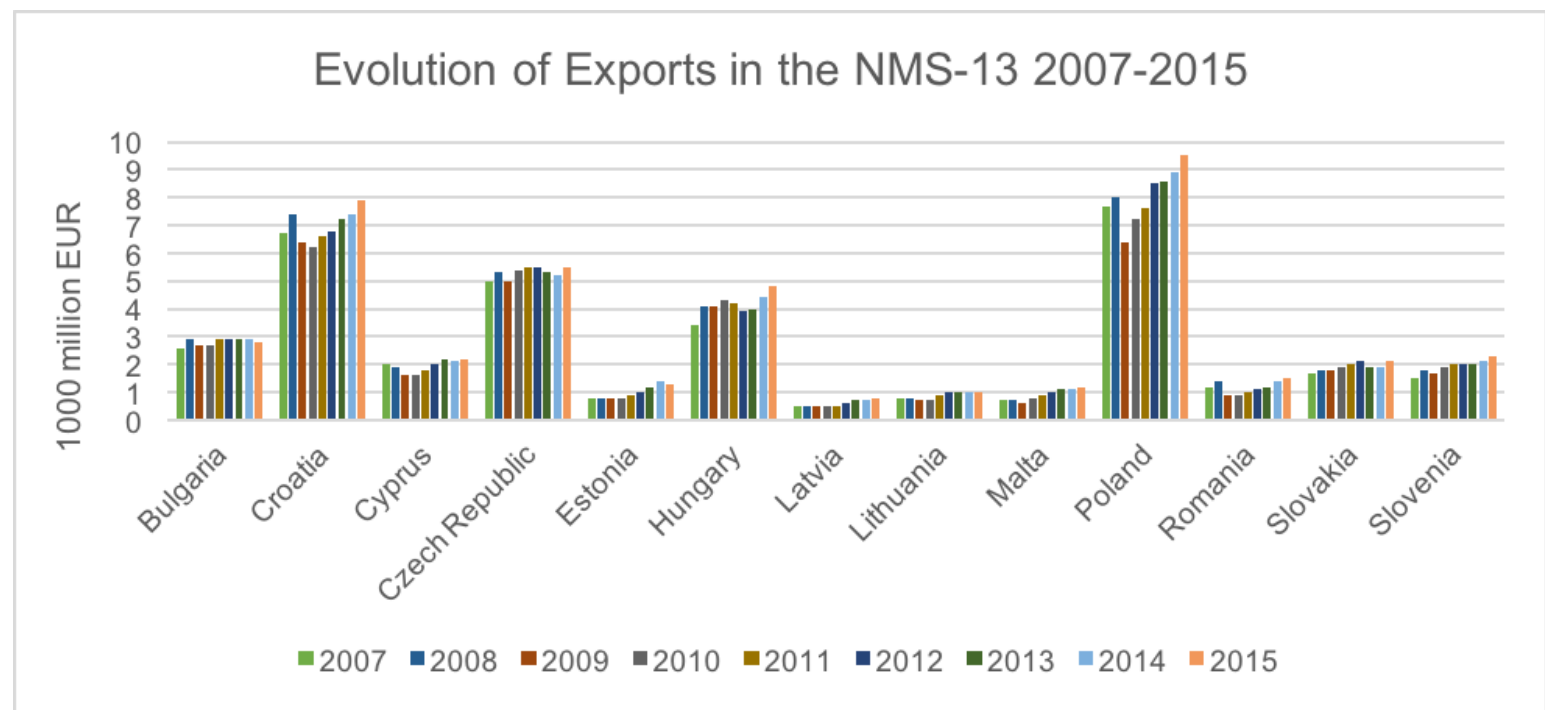

Figure 4. Evolution of exports in travel in the NMS-13 2007-2015

Source: Author's work, based on data from Eurostat.

Table 1. Exports in Travel in the NMS-13 2007-2015

Bulgaria
Croatia
Cyprus
Czech Republic
Estonia
Hungary
Latvia
Lithuania
Malta
Poland
Romania
Slovakia
Slovenia
NMS TOTAL
\% change

$\begin{array}{rrrrrrrrr}\mathbf{2 0 0 7} & \mathbf{2 0 0 8} & \mathbf{2 0 0 9} & \mathbf{2 0 1 0} & \mathbf{2 0 1 1} & \mathbf{2 0 1 2} & \mathbf{2 0 1 3} & \mathbf{2 0 1 4} & \mathbf{2 0 1 5} \\ 2.6 & 2.9 & 2.7 & 2.7 & 2.9 & 2.9 & 2.9 & 2.9 & 2.8 \\ 6.7 & 7.4 & 6.4 & 6.2 & 6.6 & 6.8 & 7.2 & 7.4 & 7.9 \\ 2 & 1.9 & 1.6 & 1.6 & 1.8 & 2 & 2.2 & 2.1 & 2.2 \\ 5 & 5.3 & 5 & 5.4 & 5.5 & 5.5 & 5.3 & 5.2 & 5.5 \\ 0.8 & 0.8 & 0.8 & 0.8 & 0.9 & 1 & 1.2 & 1.4 & 1.3 \\ 3.4 & 4.1 & 4.1 & 4.3 & 4.2 & 3.9 & 4 & 4.4 & 4.8 \\ 0.5 & 0.5 & 0.5 & 0.5 & 0.5 & 0.6 & 0.7 & 0.7 & 0.8 \\ & & & & & & & & \\ 0.8 & 0.8 & 0.7 & 0.7 & 0.9 & 1 & 1 & 1 & 1 \\ 0.7 & 0.7 & 0.6 & 0.8 & 0.9 & 1 & 1.1 & 1.1 & 1.2 \\ 7.7 & 8 & 6.4 & 7.2 & 7.6 & 8.5 & 8.6 & 8.9 & 9.5 \\ 1.2 & 1.4 & 0.9 & 0.9 & 1 & 1.1 & 1.2 & 1.4 & 1.5 \\ 1.7 & 1.8 & 1.8 & 1.9 & 2 & 2.1 & 1.9 & 1.9 & 2.1 \\ 1.5 & 1.8 & 1.7 & 1.9 & 2 & 2 & 2 & 2.1 & 2.3 \\ \mathbf{3 4 . 6} & \mathbf{3 7 . 4} & \mathbf{3 3 . 2} & \mathbf{3 4 . 9} & \mathbf{3 6 . 8} & \mathbf{3 8 . 4} & \mathbf{3 9 . 3} & \mathbf{4 0 . 5} & \mathbf{4 2 . 9} \\ \mathbf{1 3 \%} & \mathbf{8 \%} & \mathbf{- 1 1 \%} & \mathbf{5 \%} & \mathbf{5 \%} & \mathbf{4 \%} & \mathbf{2 \%} & \mathbf{3 \%} & \mathbf{6 \%}\end{array}$

Source: Authors' own research, based on data from Eurostat.

All the indicators considered, the number of international arrivals, the number of international overnight stays, and the exports in travel pointed out that the same three countries, namely that Poland, Czech Republic and Croatia were key destinations for tourism among the NMS in the period 2007-2015.

\section{Key countries for tourism: Poland, Czech Republic and Croatia}

In this section, the three countries previously identified will be analyzed from the tourism industry point of view. Main sources of tourists, the most important 
destinations and types of tourism or tourism policies in place are some of the features taken into consideration, as the success of their travel and tourism strategies is not limited to the external factors, but also heavily influenced by the internal resources of the countries and how they manage to take advantage of them (Luštický and Kincl, 2012)

\section{Poland}

Poland became a member of the EU on May 1st, 2004 and in 2007 joined the Schengen Area. This was a great advantage for the tourism industry of Poland, as it allowed for full freedom of movement within most of the EU area. During the crisis, Poland was considered to be "the surprise of the former Eastern Europe", as it managed to pass easily through the difficult times, with economic growth most of the period, mainly as a consequence of "efficient use of European funding, including European Structural Funds, with an extremely high degree of absorption” (Ion and Frățilă, 2016, pp. 233) and also due to its strong industrial sector. Tourism industry has performed anything worse either. According to the Organization for Economic Co-operation and Development (OECD Tourism Trends and Policies 2016, 2016, p. 250), tourism contributes to roughly 5\% to Poland's GDP, with the number of international incoming tourists gradually increasing yearly. Poland ranked $16^{\text {th }}$ in top most visited countries in the world in 2015 (Salamanca, 2015) and 10 ${ }^{\text {th }}$ in Europe (World Tourism Organization, 2016).

As per Euromonitor International (Travel in Poland, 2016), the key reasons for Poland's tourism industry success includes the well-developed air travel, accommodation, conferences infrastructure, as well as online booking systems, but also the country's stable political and economic environment. The active touristic marketing campaigns put in place in Poland to promote this country as a holiday destination are useful tools and relevant examples of "best practices" for the travel and tourism industry worldwide. The one responsible for tourism-related matters is the Ministry of Sport and Tourism, represented by the Polish Tourism Organization with offices in 14 international markets. Regional and local tourism organizations, as well as autonomous bodies are also involved in tourism promotion, together with the Polish Tourism Organization, based on equal rights partnerships. The main focus of Poland's national tourism policy is on competitiveness, innovation and sustainable development.

According to OECD (OECD Tourism Trends and Policies 2016, 2016, p. 253), the top source markets for inbound tourism are Germany, Ukraine, Russian Federation, Belarus and Lithuania. Warsaw and Krakow rank $73^{\text {rd }}$ and $75^{\text {th }}$ in the Top 100 City Destinations Ranking (Geerts, 2017). Małopolska (Południowy) is the most visited region in Poland according to Eurostat regional database, area that includes the historical capital of Poland, Cracow, where there are plenty UNESCO World Heritage attractions, but also castles, cathedrals, and a Jewish quartier with a 16th century cemetery and seven synagogues. Małopolska voievodeship also hosts the Auschwitz concentration camp, listed as UNESCO World Heritage, memorial museum that attracted roughly 1.7 million tourists in 2015, with this number increasing yearly. Zakopane, Poland's winter capital, Tatra Mountains, the so-called Polish Alps, Krynica spa or the Pieniny National Park known from rafting through the Dunajec Gorges are 
other important attractions of the region. Some of the main programs and initiatives for Małopolska region's tourism development were Małopolska Region Unesco Route, Wooden Architecture Route, Małopolska Traditional Craft Route, the expansion of Cultural Air-Park in Cracow or the organization of periodic festivals such as Małopolska Cultural Heritage Days (Piotrowski et all, 2010, p. 20). The Mazovian voievodeship is the second most visited region in Poland, the main attraction here being the capital, Warsaw, which welcome approximately 1.2 million international tourists in 2015, 70.7\% of them being from Europe (Statistical Office in Warsaw, 2016).

The most important document for tourism in Poland for the period 2007-2015 is called "Directions for Tourism Development 2015", according to which the focus for Polish tourism industry is business tourism, followed by urban and cultural tourism, rural tourism, and recreational and active tourism. The second most important document for Poland's tourism was "Marketing Strategy in Polish tourism sector for the period 2008-2015", prepared by Polish Tourism Organization. This document set directions and identified forms of actions in the Polish tourism sector. Conferences, congresses and business travel, tourist products that belong to business tourism were the most important for the country, followed by religious tourism, health and medical tourism - as per Ile and T,igu (2017) Poland is one of the most famous developing countries branded as destinations for medical tourism-, urban and cultural tourism, rural tourism (ecotourism and agro-tourism), recreational tourism (sea and sun, mountains, lakes, hiking) and active tourism (horse riding, cycling - supported by the EuroVelo Carpathian Cycle Route, winter sports, windsurfing, sailing) (Piotrowski et all, 2010, p. 16). The Marketing Strategy in Polish tourism sector was firstly promoted in countries like Germany, UK, USA, Norway, France, Lithuania and Belgium, this being considered to be the most important for Poland's tourism.

In what regards the support received from the EU, it is a well-known fact that Poland is and used to be the largest beneficiary of EU funds, more than half of the money needed for the projects undertaken so far coming from the EU. According to the official information portal of the Republic of Poland, run by the Ministry of Foreign Affairs (EU Funds in Poland, 2017), the largest share of funds was spent on building express roads and motorways and the second largest recipient was the Polish railways. These huge investments contributed to tourism development in Poland, as not only citizens, but also tourists were able to commute more easily, were more willing to pay for these kind of services, as it was a good value for money and the incentive to travel inside Poland's territory was greater. As per Nistoreanu and Stoian (2017), transport infrastructure is one of the most important factors in attracting and managing tourists flows. Furthermore, historic buildings were restored, sports facilities, science and technology parks and sewage treatment plants were constructed, all using mainly EU funds. An interesting example of touristic attraction revitalized with EU funds is the adaptation for tourism of the Groty Nagorzyckie caves that represent what remained of a sand mine located near glassworks. The EU cofinanced the project with around two-thirds of its total costs.

From 2007 to 2015, five Polish destinations won the "EDEN" award from the EU, namely the Bird Republic in Warta Mouth (2009), whose main attraction is bird watching, the Biebrza Valley and Wetlands (2010) - one of the biggest national parks 
in Europe, the ideal place for a vacation in unspoiled surroundings, Zyrardow (2011) Winner in the Tourism and Regeneration of Physical Sites category, regeneration that began in 2004 and focused on rebuilding and renovating an area of estate housing, reviving production and trade activities, Przemysl (2013) - barrier free conditions for the use of tourism services by disabled people, seniors and families with children were created here, in southeastern Poland, at the foot of the Carpathians, project that also meets the requirements for Calypso and the Silesian Tastes Culinary Route (2015) - enabled the tourists to combine regional cuisine with interesting tourist landmarks, to experience the history, culture and gastronomy of the Silesian region (European Commission, 2017). When it comes to projects for youth, there has not been much done in Poland specifically targeting the "millennials", except for an international hostelling search engine (Martin, 2010).

\section{Czech Republic}

On May 1'st 2004 Czech Republic, the 13 ${ }^{\text {th }}$ largest country in Europe (according to population) became a Member of the EU. The Czech Republic economy gets considerable income from the tourism industry, making up 7.8\% of country's GDP (Knoema, 2016), with Prague ranking 22nd in 2015 in top 100 destinations in the world and being the $4^{\text {th }}$ most visited city in the EU, after London, Paris and Rome according to a report published by Euromonitor International (Geerts, 2017). Except for Prague, which accounts for roughly $62 \%$ of the total number of nights spent by international non-residents in the Czech Republic according to Eurostat (2017), other popular destinations in Czech Republic are Severozápad and Severovýchod - 22\% of the total number of nights spent by international non-residents in the Czech Republic (Eurostat, 2017), regions that together form North Bohemia. These provinces include the Karlovy Vary, Mariánské Lázně, Františkovy Lázně and Jáchymov spa towns, the Ore Mountains, the Czech Switzerland national park, the Lusatian Mountains and Jizera Mountains, protected landscape areas. South Bohemia - 10\% of the total nights recorded in Czech Republic (Eurostat, 2017) is another area in which international tourists decide to spend their holiday. It offers both countryside landscapes and natural beauty, but also historical monuments and great infrastructure for cycling and water sports (Czech Tourism Office, 2017). As per the Czech Tourism Office (2017), cultural heritage, health and spa (both for relaxation and medical tourism), hiking, skiing and clubbing are the main reasons for travel for foreign tourists, while business tourism accounts for roughly $1 / 4$ of the total number of international incoming tourists in Czech Republic by reason for travel.

The main sources of tourists for Czech Republic are, by market share, according to Eurostat (Number of trips by country/world region of destionation, 2017) and the Czech Tourism Office (2017), Germany, United Kingdom, Russia, Italy, USA, Poland, Slovakia, France, Spain, the Netherlands, Austria and Japan. Plus, the number of arrivals and overnights spent in Czech Republic by residents of Russia, Turkey and NMS, such as Croatia, Romania or Slovenia are gradually increasing. South Korea, China or Brazil are the newest markets outside Europe from where the number of tourists is progressively growing. By the amount of average daily expenditure, the main source markets are Russia (approximately 71 EUR per day), USA, UK, Italy and Japan (OECD, 2016).

Vol. 13, No. 1, Spring, pp. 812-830, ISSN 1842-0206 | Management \& Marketing. Challenges for the Knowledge Society 
In what regards the vision and objectives of the Czech Tourism Authority, they mainly aim to create a new perception of the country, as it is apparently still perceived as a communist destination. In addition to convincing foreigners to discover the beautiful parts of the Czech Republic and to prove them the potential of still undiscovered regional places, the Czech Tourism Agency's objectives also include increasing the repetition of visits and the satisfaction of tourists (Czech Tourism Office, 2017).

In promoting Czech Republic, Czech Tourism Agency launched the marketing campaign called "Czech Republic: A Country Full of Stories", which focuses on journeys of discovery the country through unique cultural elements, gastronomy, traditions and customs. International tourism fairs, brochures and maps or press trips are some of the main promotion tool used by the Czech Tourism Agency, represented in 21 countries all over the world. This agency is "a grant-aided organization supported by the Ministry of Regional Development" (OECD, 2016, p. 149), whose main source of funding was EU Structural Funds. The National Tourism Policy for the period 2014-2020 is "Destination Czech Republic - number one in the heart of Europe", with a global objective to increase the competitiveness of the tourism sector at the national and regional levels and maintain its economic performance as a result of achieving a balance between economic, socio-cultural, environmental and regional development (Idem, p. 150).

According to an official report undertaken by the responsible Czech Republic bodies (The Ministry of Regional Development, 2015), a National Support Program for Tourism was implemented for the period 2010-2017, with grants covering a maximum of $50 \%$ of project funding and the rest coming from the applicant's own resources. One of the main sub-programs developed under this project is called "Tourism for All", launched in 2010, "focuses on creating new products for the domestic tourism sector including marketing support for, and the implementation of, newly-created products (e.g. wheelchair access, children's playrooms, playgrounds, mobile swimming pools, and equipping classrooms for school camps)" (Idem, p. 7). In 2011 a new sub-program was announced, "Tourism Accessible for All", targeting reconstruction/building a rest places, sanitary facilities for tourists, cyclists and disabled travelers. 63 projects were already subsidized, the total granted allocation reaching 2.7 mill EUR. Czech Republic also participated in the EDEN Competitions and five destinations were selected as winners in the period 2007-2009, namely: Bohemian Switzerland (2009), also known as Czech Switzerland, a protected area, with a multitude of great natural attractions, Bystricko (2010) - a micro-region comprising of 34 towns and villages, Slovacko (2011) - Winner in the Tourism and Regeneration of Physical Sites category, Lipno (2013) - one of the most attractive destinations in the Czech Republic, with most attractions and activities being open all year and accessible to disabled people and Jeseniky (2015), winner in the Tourism and Local Gastronomy category with the project "Taste Jeseniky", for which the total allocation reached 51.355 EUR. The Ministry of Regional Development granted an additional amount of 15.000 EUR for marketing activities related to EDEN (European Commission, 2017). 


\section{Croatia}

Classified by the World Bank as a high-income economy (World Bank Country and Lending Groups, 2017), Croatia is the $28^{\text {th }}$ and latest member of the EU, acceding on the $1^{\text {st }}$ of July 2013. The service sector has a 70\% share of Croatia's GDP, with tourism accounting for roughly 20\%, meaning that tourism plays a significant role in Croatia's development (OECD, 2016, p. 326). According to Eurostat (2017), most of the foreign visits in Croatia were by visitors from the EU, with Germany ranking first in the period 2007-2015 (approximately 13 million arrivals), followed by Italy (approximately 8.5 million arrivals), Slovenia (approximately 8.3 million arrivals), Austria (approximately 7.5 million arrivals) and Czech Republic (approximately 4.2 million arrivals). UK, USA, Montenegro, Bosnia and Herzegovina are also relevant countries for Croatia's tourism.

Compared with other NMS, Croatia's tourism has a stronger seasonality component, being mainly based on sun and sea type of tourism. For this reason, the latest tourist campaign launched in July 2014 by the Croatian National Tourist Board, Croatia 365, strives to make Croatia a four-season destination. Famous magazines and websites, such as "Lonely Planet" or "National Geographic Adventure Magazine" named Croatia as the top pick destination several years in a row, and, ever since, Croatia's touristic appeal has been increasing, now being the $25^{\text {th }}$ most visited country in the world (Salamanca, 2015). The increase in FDI in both tourism and auxiliary infrastructure, the rise in the number of protected tangible and non-tangible attractions, the great variety of touristic product offerings and the fact that Croatia has been starred in a famous HBO TV series have contributed to the boost reported for the tourism industry in Croatia.

The current tourism strategy was launched in 2013 and seeks EUR 7 billion in new investments in tourism by 2020 . These are mainly directed to hotels, rural homesteads and private individuals able to attract tourists outside summer months, increase tourism expenditure, create new jobs, improve quality of tourism services and decrease the turnover rate, while diversifying touristic offering. Cultural, gastronomic and sport events, as well as thematic parks and cycling routes are among the Croatian tourism industry's priorities. A system of certifications and designations has been introduced, assuring visibility and recognition for public and private bodies in the tourism sector. Given the high influence e-tourism and Social Media has had recently, the Ministry of Tourism implemented a HOT-SPOT program to support free internet access in tourist destinations in Croatia. This aims to improve the competitiveness of Croatian tourism by providing free Wi-Fi at the most popular tourist areas, stimulate additional tourism expenditure and raise awareness.

Adriatic Croatia, region that forms the coastal part accounts for half than the country's territory, but attracts roughly $90 \%$ of the total number of tourists in Croatia. The most popular cities in the area are Dubrovnik, Split and Zadar, plenty of UNESCO Heritage Attractions being found in the region. Plitvice Lakes in Central Croatia reports more than 1 million visitors per year and the capital city of Zagreb is a serious competitor for other popular Central European cities such as Prague or Budapest. According to statistics, Zagreb is the city with the most museums per square foot in the world, so cultural tourism is one of the main reasons for travel in the central part of the country. 
One of the Croatian highlights that differentiate it from other destinations in the world is the presence of naturist resorts, an industry for which Croatia is really famous (Lonely Planet, 2017) and over 1 million visitors that come to Croatia each year (roughly $10 \%$ of the total according to Eurostat (2017)) are involved with naturism. Furthermore, Croatia has 116 Blue Flag beaches (certification that a beach meets stringent standards imposed by the Foundation for Environmental Education) and numerous nature reserves.

Since 2007, although not yet a member of the EU then, Croatia successfully attended all EDEN thematic calls. In 2007, Sveti Martin na Muri won in the Best Emerging Rural Destination category, combining nature and ecology with culture and tradition, food and wine. In 2008 Durdevac was the winner in the Tourism and Local Intangible Heritage category and in 2009 the Northern Velebit National Park was the winner of EDEN Tourism and Protected Areas category. Nin (2010 - winner in the Aquatic Tourism Category), known for its healing mud natural heritage, Pustara Visnjica (2011 - winner in the Tourism and Regeneration of Physical Sites category), Stancija 1904 (2013 - winner in the Accessible Tourism category) and Gornje Medimurje (2015 - Winner in the Tourism and Local Gastronomy category) are all EDEN Destinations, which after receiving the award benefited from greater visibility and better positioning. All marketing activities after the award got much larger media attention according to Croatia's Annual Report sent to the Commission (The Ministry of Tourism, 2016).

\section{Conclusion}

Tourism is an important sector for the economy of the New Member States, accounting for roughly $12 \%$ of their GDP, total contribution, while the direct contribution of travel and tourism to the NMS is approximately $5 \%$. Tourism is also an important sector for nature, society and cultures, and can lead to important improved community services, reduce unemployment, increase standard of living and balance of payment, but may also lead to loss of identify and local culture or harm the environment. The main conclusions drawn based on the analysis conducted for the periods considered, 2007-2015, reflect the following:

a. The tourism industry is on an ascending path in the NMS-13 of EU, and in the period 2007-2015 high levels of increase for all the studied indicators were recorded. It looks like the NMS are catching up and try to fill in the existing gap between them and the OMS-15, taking great advantage of the opening of new markets and of the existing EU support funds and policies. In terms of tourist flows, $15 \%$ of the total number of incoming tourists reported at EU-28 level can be directly attributed to the NMS.

b. Of the thirteen NMS, Poland, Czech Republic and Croatia recorded the highest number of incoming tourist, highest number of international overnight stays and performed the best in terms of exports in travel in the period 2007-2015. Most of the tourists come from the EU, from neighborhood countries, as a consequence of geographical proximity, presumably higher cultural similarity and reasonable prices.

c. The factors that affected the tourism industry in the NMS the most are the European integration process, the diversification of tourism preferences of 
citizens worldwide, the growing desire to travel and higher budgets designated to this activity, as well as low-cost airlines expansion, the development of etourism, the changes in lifestyle and nature of employment, or the improvements made in the visa sectors lately.

d. Poland, Czech Republic and Croatia offer rather unique adventures - here tourists can interact with locals, observe their traditions and live meaningful experiences, this being their competitive advantage compared to the OMS, what they bring new in the sector, differentiate themselves. Plus, all the three countries tend to focus on niche markets rather than on mass-market tourism. They all benefit of natural heritage landmarks, UNESCO-listed attractions to which the tourism bodies in charged pay high importance.

EU policies seem to have been beneficial for the NMS, as touristic markets have opened. The European bodies and the national authorities have been working together for the same purpose, of increasing the tourism's importance for the economy of the Member States. Financial support for tourism under regional policy is mostly provided from the European Structural and Cohesion Funds. Numerous projects and initiatives have been designed, addressing the main types of tourism in the NMS, but also the areas where there are still improvements to be made, such as the tourism for people with disabilities or for people that cannot afford to travel in high seasons, this way also overcoming the seasonality problem encountered in almost all Member States. Poland, Czech Republic and Croatia took advantage of all the European calls and won various tourism-related challenges, receiving not only funding, but also guidance and support to improve their performance in the tourism industry. Community-based tourism, adventure tourism, gastronomy tourism, agrotourism, cultural and religious tourism seem to be the segments that offer the best opportunities for tourism in Poland, Czech Republic and Croatia.

\section{References}

Attila, A.T. (2016), "The Impact of the Hotel Industry on the Competitiveness of Tourism Destinations in Hungary", Journal of Competitiveness, Vol. 8, No. 4, pp. $85-104$.

Bâc, D.P. (2015), “Endogenous Challenges for the Tourism Industry”, Quaestus Multidisciplinar Research Journal, No. 6/April 2015, pp. 231-239.

Bodosca, S.L. (2016). "Priorities and strategies of sustainable development in tourism" in: Proceedings of the $10^{\text {th }}$ International Conference on Business Excellence, Bucharest, Academy of Economic Studies, pp. 207-217.

Czech Tourism Office (2017), “About CZT" available at: https://www.czechtourism.com/about-czt/ (accessed April 9, 2017).

Czech Tourism Office (2017), "South Bohemia", available at: https://www.czechtourism.com/a/south-bohemia/ (accessed April 8, 2017).

Diaconescu, M., Nicolescu, L. and Pânzaru, F. (2007), "The European Identity between reality and hope", in: Romania within the EU: opportunities, requirements and perspectives Conference, Sibiu, Lucian Blaga University, Vol. 1, pp. 135-141.

Dupeyras, A. and MacCallum, N. (2013), "Indicators for Measuring Competitiveness in Tourism: A Guidance Document”, OECD Tourism Papers, February. pp.20-24. 
Euromonitor International (2016), "Travel in Poland. Country Report”, Euromonitor International Euromonitor International: London.

European Commission (2010), "Communication from the Commission to the European Parliament, the Council, the European Economic and Social Committee and the Committee of the Regions - Europe, the world's No 1 tourist destination - a new political framework for tourism in Europe", Brussels, Belgium, available at: http://eur-lex.europa.eu/legal-content/EN/ALL/?uri=CELEX\%3A52010DC0352 (accessed March 20, 2017).

European Commission (2010), "Overview of EU Tourism Policy", available at: https://ec.europa.eu/growth/sectors/tourism/policy-overview_en (accessed October 29, 2016).

European Commission (2015), "Flash Eurobarometer 414 Preferences of Europeans Towards Tourism”, European Commission European Commission, DirectorateGeneral for Internal Market, Industry, Entrepreneurship and SMEs: Brussels.

European Commission (2016), “About EDEN”, available at: https://ec.europa.eu/growth/toolsdatabases/eden/about_en (accessed November 15, 2016)

European Commission (2017), "Eden Destinations Czech Republic", available at: https://ec.europa.eu/growth/tools-databases/eden/destinations/czech-republic_en (accessed April 11, 2017).

European Commission (2017), “Eden Destinations: Poland”, available at: https://ec.europa.eu/growth/tools-databases/eden/destinations/poland_en (accessed, April 10, 2017).

European Commission (2017), "Low Season Tourism", available at: http://ec.europa.eu/growth/sectors/tourism/offer/seniors-youth_en (accessed January 17, 2017).

Eurostat (2016), "Expenditure by expenditure categories (from 2012 onwards)", available at: http://appsso.eurostat.ec.europa.eu/nui/show.do?dataset=tour_dem_exexp\&lang=en (accessed January 22, 2017).

Eurostat (2017), "Nights spent at tourist accommodation establishments by NUTS 2 regions", available at: http://ec.europa.eu/eurostat/web/regions/data/maintables (accessed, April 9, 2017).

Eurostat (2017), "Number of trips by country/world region of destination", available at: http://ec.europa.eu/eurostat/en/web/products-datasets/-/TIN00190 (accessed April $9,2017)$.

Fouloy, C.D. (2015), "Challenges for the European Tourism Industry" available at: http://www.aalep.eu/challenges-european-tourism-industry (accessed, March 8, 2017).

Gajdošík, T., Hrubcová, G., Šrámek, J. and Tittelbachová, Š. (2015), “Approaches to the Economization of Cultural Heritage in Context of Destination Management in the Czech Republic", Journal of Competitiveness, Vol. 7, No. 1, pp. 22-34.

Geerts, W. (2017), “Top 100 Destinations Ranking”, Euromonitor International Euromonitor International: London, United Kingdom.

Halkier, H. (2010), "EU and Tourism Development: Bark or Bite?", Scandinavian Journal of Hospitality and Tourism, Vol. 10, No. 2, pp.92-106.

Hudman, L.E. and Jackson, R.H. (2003), "Geography of Travel and Tourism”, 4th Ed., Delmar Learning, New York. 
Ile, F. \& Țigu, G. (2017), "Medical tourism market trends - an exploratory research" in: Proceedings of the $11^{\text {th }}$ International Conference on Business Excellence, Bucharest, Academy of Economic Studies, Vol. 1, No. 1, pp. 1111-1121.

Ion, L. \& Frățilă, L. (2016), "The importance of developing sustainable development as a key factor of economic efficiency" in: Proceedings of the 10th International Conference on Business Excellence, Bucharest, Academy of Economic Studies, pp. 231-241.

Knoema (2016), "Czech Republic - Travel \& Tourism Total Contribution to GDP Travel \& Tourism Total Contribution to GDP - \% share", available at: https://knoema.com/atlas/Czech-Republic/topics/Tourism/Travel-and-

Tourism-Total-Contribution-to-GDP/Total-Contribution-to-GDP-percent-share (accessed April 7, 2017).

Lonely Planet (2017), “Croatia Travel Guide", available at: https://www.lonelyplanet.com/croatia (accessed April 10, 2017).

Luštický, M. and Kincl, T. (2012), "Tourism Destination Benchmarking: Evaluation and Selection of the Benchmarking Partners", Journal of Competitiveness, Vol. 4, No. 1, pp. 99-116.

Martin, A. (2010), "Calypso Study on Social Tourism Poland. Country Report”, Ministry of Sport and Tourism, Warsaw.

Ministry of Foreign Affairs (2017): "EU Funds in Poland", available at: https://poland.pl/economy/investments-projects/eu-funds-poland/ (accessed April 10, 2017).

Mureşan, M., Chiripuci, B. \& Nistoreanu, P. (2017), "Business tourism - a sustainable form to relaunch Romanian tourism" in: Proceedings of the $11^{\text {th }}$ International Conference on Business Excellence, Bucharest, Academy of Economic Studies, Vol. 1, No. 1, pp. 1101-1110.

Nistoreanu, B. \& Stoian, R. (2017), "Business tourism a means of dynamising the life of local communities" in: Proceedings of the $11^{\text {th }}$ International Conference on Business Excellence, Bucharest, Academy of Economic Studies, Vol. 1, No. 1, pp. $1122-1128$.

OECD (2016), "OECD Tourism Trends and Policies 2016", OECD Publishing OECD Tourism Committee: Paris, ISBN: 9789264245990

Piotrowski, M., Soliński, T., Pacholska, M. and Warzybak, B. (2010): "Analysis of the Situation of the SMEs in Tourism Sector in Malopolska and Podkarpackie Regions. Regional Tourism Report", Warsaw: Bench Tour University of Information, Technology and Management in Rzeszów; CASE-Advisors Ltd. in Warsaw.

Salamanca, A. (2015), "25 Most Visited Countries in the World", available at: http://list25.com/25-most-visited-countries-in-the-world/2/ (accessed April 9, 2017).

Sardianou, E., Kostakis, I., Mitoula, R., Karamba, M. and Theodoropoulou, E. (2015), "Barriers And Drivers To Sustainable Tourism Development: Evidence From Greece", in: K.H. Collins (ed.), Handbook On Tourism Development And Management, $1^{\text {st }}$ Ed., pp. 221-227, Nova Science Publishers, New York.

Sharpley, R. and Telfer, D.J. (2015), “Tourism and Development: Concepts and Issues”, Channel View Publications, Bristol. 
Statistical Office in Warsaw (2016), "Tourism in the Capital City of Warsaw in 2015", and Mazovian Centre of Regional Survey, available at: warszawa.stat.gov.pl/download/gfx/warszawa/en/./turystyka_waw_ang_2015 .pdf (accessed April 10, 2017).

The Ministry of Regional Development (2015), "Annual Report on Tourism Czech Republic. Annual Report", The European Commission, The Ministry of Regional Development: Prague.

The Ministry of Tourism (2016), "Annual Report on Tourism Croatia", The Ministry of Tourism, Zagreb.

The World Bank (2017), "World Bank Country and Lending Groups", available at: https://datahelpdesk.worldbank.org/knowledgebase/articles/906519\#High_in come (accessed April 10, 2017).

TNS Political and Social (2015), "Flash Eurobarometer 414 "Preferences of Europeans towards tourism 2015"”, Eurobarometer, European Commission European Commission, Brussels.

Weiermair, K. (2003), "Product Improvement or Innovation: What is the Key to Success in Tourism?", in Innovation and Growth in Tourism, OECD Publishing: Lugano.

Weston, R., Davies, N., Lumsdon, L. and McGrath, P. (2012), "The European Cycle Route Network EuroVelo Challenges and Opportunities for Sustainable Tourism", European Parliament Directorate General for Internal Policies, Brussels.

World Tourism Organization (2016), "International tourism trends in EU-28 member states Current situation and forecasts for 2020-2025-2030", European Commission, available at: http://ec.europa.eu/growth/tools-

databases/newsroom/cf/itemdetail.cfm?item_id=8828\&lang=en (accessed March 25, 2017).

World Tourism Organization (2016), "Methodological Notes to the Tourism Statistics Database", Madrid, Spain, available at: http://cf.cdn.unwto.org/sites/all/files/pdf/methodological_notes_2016_en.pdf (accessed March 25, 2017).

World Tourism Organization (2016), "UNWTO Tourism Highlights. Annual Report", UNWTO United Nations: Madrid.

World Travel \& Tourism Council (2016), "Economic Impact Analysis Country Reports", available at: http://www.wttc.org/research/economicresearch/economic-impact-analysis/country-reports\#undefined (accessed January 22, 2017). 